\title{
Maternal HIV disclosure to HIV-uninfected children in rural South Africa: a pilot study of a family-based intervention
}

\author{
Tamsen J Rochat ${ }^{1 *}$, Ntombizodumo Mkwanazi ${ }^{2}$ and Ruth Bland ${ }^{3}$
}

\begin{abstract}
Background: As access to treatment increases, large numbers of HIV-positive parents are raising HIV-negative children. Maternal HIV disclosure has been shown to have benefits for mothers and children, however, disclosure rates remain low with between $30-45 \%$ of mothers reporting HIV disclosure to their children in both observational and intervention studies. Disclosure of HIV status by parent to an HIV-uninfected child is a complex and challenging psychological and social process. No intervention studies have been designed and tested in Southern Africa to support HIV-positive parents to disclose their status, despite this region being one of the most heavily affected by the HIV epidemic.

Method: This paper describes the development of a family-centred, structured intervention to support mothers to disclose their HIV status to their HIV-negative school-aged children in rural South Africa, an area with high HIV prevalence. The intervention package includes printed materials, therapeutic tools and child-friendly activities and games to support age-appropriate maternal HIV disclosure, and has three main aims: (1) to benefit family relationships by increasing maternal HIV disclosure; (2) to increase children's knowledge about HIV and health; (3) to improve the quality of custody planning for children with HIV-positive mothers. We provide the theoretical framework for the intervention design and report the results of a small pilot study undertaken to test its acceptability in the local context.

Results: The intervention was piloted with 24 Zulu families, all mothers were HIV-positive and had an HIV-negative child aged 6-9 years. Lay counsellors delivered the six session intervention over a six to eight week period. Qualitative data were collected on the acceptability, feasibility and the effectiveness of the intervention in increasing disclosure, health promotion and custody planning. All mothers disclosed something to their children: 11/24 disclosed fully using the words "HIV" while 13/24 disclosed partially using the word "virus".

Conclusion: The pilot study found the intervention was feasible and acceptable to mothers and counsellors, and provides preliminary evidence that participation in the intervention encouraged disclosure and health promotion. The pilot methodology and small sample size has limitations and further research is required to test the potential of this intervention. A larger demonstration project with 300 families is currently underway.
\end{abstract}

Keywords: Intervention, HIV-disclosure, Family-centred, Maternal HIV-disclosure

\footnotetext{
* Correspondence: trochat@africacentre.ac.za

'Africa Centre for Health and Population Studies, University of KwaZulu-Natal,

Mtubatuba, South Africa, and Department of Psychology, Stellenbosch

University, Stellenbosch, South Africa

Full list of author information is available at the end of the article
} 


\section{Background}

Prevention of Mother-to-Child HIV Transmission (PMTCT) programs in sub-Saharan Africa have been extremely successful in reducing the numbers of children infected with HIV [1]. In South Africa with its extensive use of effective PMTCT regimens new HIV infections in infants in the future should be rare [2,3]. However, in high HIV prevalence areas, at least $40 \%$ of pregnant women may be HIV-infected, and as a consequence large numbers of HIV-uninfected children are being cared for by at least one HIV-infected parent [4]. HIV-infected mothers face the dilemma of when, and how, to disclose their own HIV status to their children [5-7].

Research, mainly from the United States of America (USA) and Europe, has shown that maternal HIV disclosure has benefits for mothers and children [8-10], including improvements in maternal mental health [11-14] and the quality of relationship between mother and child $[9,10]$, increased preparation for the child's future in terms of custody and care planning for emergencies $[8,15,16]$, and improvements in children's emotional and social functioning $[16,17]$. However, disclosure rates remain low with between $30-45 \%$ of mothers reporting HIV disclosure to their children in both observational and intervention studies [5-7,18,19]. Only a few studies have explored paternal HIV disclosure [20-23], and most intervention research has focused on mothers disclosing to their children. While the reasons for this are likely pragmatic since the majority of HIV-affected children live with, and are cared for, primarily by their mothers, this exclusion of fathers (whether biological or social) is increasingly critiqued in the literature on family interventions in the context of HIV [24].

There is limited research relating to maternal HIV disclosure in the African context [7], and few studies globally have targeted mothers with primary school-aged children [9,25-27]. Only one recent intervention study from the United States (US) evaluated a maternal HIV disclosure intervention (the TRACK program) targeted at primary school-aged children [28], demonstrating that disclosure interventions in pre-adolescence are not only feasible, but also effective among mothers who had no intention to disclose to their children at the start of the study. TRACK was a randomized controlled trial of an intervention which included three home visits, telephone support and educational materials. Intervention mothers were over four times more likely to disclose, with a disclosure rate of $33 \%$ in the intervention compared to $7.3 \%$ in the control arm.

More generally in the literature, mothers frequently express the desire to disclose their HIV status to their children themselves, but report feeling unsure about how to approach the issue $[18,19,29,30]$; are worried about addressing matters concerning sex and sexuality $[15,31,32]$; and have concerns that disclosure may cause emotional difficulties for their child $[18,19,29]$. A significant amount of international research has been conducted on the consequences of a lack of maternal HIV disclosure among 6-18 year olds [33]. While few mothers report disclosing to their children in the primary school years many are forced to disclose before adolescence following HIV-related illnesses or hospitalisations [21], which impacts negatively on children's emotional and behaviour outcomes in case-control studies [5-7]. In most disclosure research to date mothers emphasize the need for assistance in planning and preparing towards disclosure $[5,19,29,31,32]$, an important consideration in the design of disclosure interventions for Southern Africa.

In considering approaches to maternal HIV disclosure in the Southern African context, unique challenges exist. Although the largest population of HIV-infected parents lives in Africa, very little research has examined maternal HIV disclosure to children in this region. As access to HIV treatment increases, so does exposure to HIV at a family level. For example, by January 2010, 3\% of the population in the research area had initiated ART, and as a result $40 \%$ of the population shared household or living arrangements with people who had either started ART or were enrolled into pre-ART care [34]. Therefore, children living in communities where ART is being scaled up are more likely to be socially exposed to HIV at younger ages. In general, increases in access to treatment also tend to reduce stigma within communities and families, allowing for more preventive activities at a household and family level [35].

Concurrently, there is growing evidence of the risks facing pre-adolescent and adolescent children growing up in HIV-affected families in Southern Africa [36-38]. Therefore, disclosure interventions that target younger children in these contexts may have the benefit of helping not only with parental disclosure but also of promoting more generalised preventive interventions including improved quality of parent-child relationships, health promotion and custody planning. Given that South Africa has the largest antiretroviral treatment (ART) programme in the world there are unique opportunities to explore psychological interventions, using family approaches, to develop culturally-appropriate disclosure interventions. These interventions should draw on existing evidence, and be feasible for integration into standard of care psychosocial support for HIV-infected parents, if found to be effective. We describe here the development and piloting of a complex psychological intervention (the 'Amagugu' a Intervention) to support age-appropriate maternal HIV disclosure to primary school-aged children, aged 6-10 years, to be delivered by lay counsellors or community health care workers in poorly resourced settings. 


\section{Methods}

\section{The research context}

The Wellcome Trust-funded Africa Centre for Health and Population Studies (www.africacentre.com) is based in rural northern KwaZulu-Natal, South Africa. HIV prevalence in 2010, within the Africa Centre Demographic Surveillance Area (DSA), that includes 90,000 adults, was $23 \%$ among adults overall [39]. Over the period 20052010 the estimated annual incidence was about $3 \%$ in adults of all ages, reaching a high of nearly $7.5 \%$ in females aged 25-29 years old and over 5\% in men 30-34 years old [40]. Whilst HIV prevalence is increasing due to the widespread availability of antiretroviral treatment (ART) there is no evidence of a declining HIV incidence since measurement started in 2003 [41]. The demographic profile of the study area shows that the majority of children live with their biological mothers, not with their fathers $[42,43]$. This intervention was therefore designed primarily for mothers, but is flexible in its inclusion of fathers as described below.

\section{The intervention aim}

The intervention package was developed to include printed materials, therapeutic tools and child-friendly activities and games to support age-appropriate maternal HIV disclosure. It has three main aims:

(1) to benefit family relationships by increasing maternal HIV disclosure;

(2) to increase children's knowledge about HIV and health;

(3) to improve the quality of custody planning for children with HIV-positive mothers.

\section{Evidence base and theoretical framework for the intervention design}

In line with the UK Medical Research Council revised guidelines for developing complex interventions [44] the Amagugu design is based on a comprehensive review of the evidence base and a clear theoretical understanding of what is needed to effect change in disclosure interventions, informed by what we know about children's development at this age and the cultural context.

A literature review on maternal HIV disclosure to children was conducted, finding a total of 58 studies, including two literature reviews $[5,6]$ and a recent systematic review [7], all of which are reported on, and summarised, by the authors in a recently published Special Report [33]. In addition we reviewed the recent guidelines from the World Health Organization on HIV disclosure to children [45] that include the available evidence on maternal disclosure to HIV-negative children of primary school-age and highlight the lack of studies on this issue.
The Amagugu design builds on a theoretical model developed from previous work $[28,46]$ and contains six steps as outlined in Table 1. The intervention is designed to provide the mother with the opportunity to receive information, and to plan and practise a series of intervention activities to be able to facilitate safe, developmentally appropriate, disclosure with her child. Fathers and other family members are encouraged to participate in activities, and the intervention can be used by other care-givers of the child. The HIV education materials developed for Session 4, 5 and 6 (see Table 1) also have the potential to be adapted for use with HIV-infected children in this age range, although this does not fall within the scope of the current study.

Once disclosure is achieved, the intervention encourages mothers to engage in health promotion activities including a clinic visit (Session 5); and to develop custody and care plans (Session 6). Importantly while the counsellor, either a lay counsellor or community health care worker (CHW), offers assistance and trains the mother towards disclosure, the mother undertakes disclosure with the child on her own. Similarly, the mother takes the child to the clinic independently, and completes a care plan and custody plan without the counsellor being present. This is to ensure parenting skills transference, self-efficacy and to build the mother's confidence to deal with HIV issues with her child. This intervention has been carefully designed to achieve specific tasks, in a specific order, each session building on the one before. The intervention process is described in detail in a train-the-trainer modelled training manual and DVD.

Three important principles related to the Southern African context informed the design and development of this intervention:

\section{Family-centred, mother-driven, approach}

There is growing acknowledgement of the key role played by families in managing the burden of HIV care in Southern Africa $[47,48]$. In this intervention when we refer to 'family' we are referring to the concept of the family relationship context within which the child is being raised, and which is the focus of this disclosure intervention. Family is thus broadly and functionally defined, suggesting that family members who are in relationship with one another, who live together and function as family, for whatever reasons, create a shared social reality for the child that is linked to the care and development of children in the context of maternal HIV illness [49-51]. The focus on the family relationship context is based on the assumption that family-like relationships have greater emotional intensity than most other social relationships and thus provide significant leverage for influencing the day-to-day care and support of children [52]. 
Table 1 The Amagugu intervention detailing the six steps, purpose of the steps, materials and activities and session goals

\begin{tabular}{ll}
\hline Session/Visit & Description \\
\hline $\begin{array}{l}\text { 1: Positive } \\
\text { parenting }\end{array}$ & $\begin{array}{l}\text { One-on-one counselling } \\
\text { session between mother and } \\
\text { lay counsellor which takes } \\
\text { place by arrangement at the } \\
\text { home }\end{array}$ \\
2: Positive families & $\begin{array}{l}\text { Family visit co-facilitated by } \\
\text { the counsellor and mother - } \\
\text { family invited by the mother } \\
\text { (either biological or socially- } \\
\text { defined members); not an HIV } \\
\text { specific activity as children are } \\
\text { present }\end{array}$
\end{tabular}

$\begin{array}{ll}\text { 3: Positive life } & \begin{array}{l}\text { One-on-one counselling } \\ \text { session between mother and } \\ \text { stories }\end{array} \\ & \text { narrative therapy activities }\end{array}$

4: Positive practices

\section{5: Positive} planning
One-on-one training session to personalise 5-step disclosure intervention and practise using role-play

Purpose
Assess mothers' readiness to
disclose, offer psycho-education
on disclosure steps,
communicate pros and cons of
disclosure, encourage an
informed decision to participate
and proceed with disclosure

Engage family members in a fun family process, create a sense of belonging and pride, use a strengths-based model,

communicate respect for culture and values, introduce concept of play-for-communication and materials

Improve emotional well-being of the mother in preparation for disclosure; use 'head, hands and heart' model to maintain empathy and introduce concepts of emotional work; use artwork to facilitate positive experiences of love, relationships and to unpack the story of becoming HIV infected and living with HIV; dispel myths and misperceptions about HIV and offer HIV information

Offer specific guidance on planning and preparing the disclosure event (time, place and people)

Teach the 5- step process and what each step offers the child

Demonstrate the 5-step disclosure intervention and teach age-appropriate activities and games

Through practice ensure that mother is skilled, confident, and feels enabled to undertake disclosure using the intervention tools and materials.

Help mother develop her own child and family personalised materials

Allow for role playing, practice and development of personal talking points

Encourage mothers to move beyond disclosure and increase health promotion and the child's access to a health support network and improve custody planning. Demonstrate clinic visit games and activities and

$\begin{array}{ll}\text { Materials and activities } & \text { Session goals } \\ \begin{array}{l}\text { My intervention steps } \\ \text { poster }\end{array} & \begin{array}{l}\text { Increase mothers' knowledge } \\ \text { about age-appropriate } \\ \text { disclosure }\end{array} \\ \text { A3 illustrated colour poster } & \end{array}$

\section{My intervention} calendar

A5 illustrated colour card

\section{My family tree}

A2 family tree poster with 14 illustrated sticker characters

\section{My life story}

A4 paper, artwork materials

\section{My HIV story}

A4 illustrated HIV story telling exercise

Talk and play reminder

A5 illustrated colour card

\section{Family life line}

A4 card artwork and stickers

\section{HIV body map}

A4 HIV body map game with stickers

\section{Playing cards}

A7 10 matching pairs playing card set

\section{Safety hand}

A4 card and pens for artwork

\section{Family treasures story book}

A5 illustrated 14 page English-Zulu story book

\section{Clinic visit reminder}

A5 illustrated colour card

\section{Name tag}

A8 name tag with beaded strap
Increase mothers' understanding of risks and benefits of disclosure

Increase family awareness of parenting aims of the intervention

Encourage a sense of belonging among all family members

Mother feels supported, respected and understood by the counsellor

Mother constructs a family/ parenting narrative

Mother more emotionally contained and able to focus on the child

Mother has confidence in her HIV specific knowledge

Mother increases her understanding of what is age-appropriate and is confident to talk about HIV in a child-friendly way

Mother develops and practises her own talking points, has a language to use in approaching disclosure

Reduce mothers' anxiety about 'dreaded questions' by developing child friendly and age-appropriate answers

Mother understands child's needs for information, activity, reassurance and comfort

Mother is confident to proceed with disclosure

Mothers move beyond disclosure to health promotion and planning

Mother is able to advocate for her and her children's health rights 


\section{Table 1 The Amagugu intervention detailing the six steps, purpose of the steps, materials and activities and session} goals (Continued)

\begin{tabular}{|c|c|c|c|c|}
\hline & & $\begin{array}{l}\text { encourage mother to take the } \\
\text { child on a clinic visit, empower } \\
\text { mother to advocate for her own }\end{array}$ & $\begin{array}{l}\text { Clinic check list } \\
\text { A4 "I-spy" game }\end{array}$ & $\begin{array}{l}\text { Mother ensures that HIV } \\
\text { treatment is demystified and } \\
\text { personalised for the child }\end{array}$ \\
\hline & & $\begin{array}{l}\text { and her child's health care needs, } \\
\text { counsel around fears and stigma }\end{array}$ & My care circle (health) & $\begin{array}{l}\text { Health care environment } \\
\text { becomes familiar }\end{array}$ \\
\hline & & & A4 illustrated card with & Increase child's participation \\
\hline & & & $\begin{array}{l}\text { health care contact } \\
\text { information }\end{array}$ & $\begin{array}{l}\text { Child has increased } \\
\text { understanding of healthy } \\
\text { sexuality }\end{array}$ \\
\hline \multirow[t]{4}{*}{ 6: Positive futures } & \multirow{4}{*}{$\begin{array}{l}\text { Family session facilitated by } \\
\text { mother and attended by } \\
\text { counsellor, provides mother } \\
\text { and children opportunities to } \\
\text { share intervention learning } \\
\text { and achievements }\end{array}$} & \multirow{4}{*}{$\begin{array}{l}\text { Reinforce play-for } \\
\text {-communication, teach mothers } \\
\text { basic skills for developmental } \\
\text { play, provide positive } \\
\text { reinforcement for emotional } \\
\text { sharing, allows the child to } \\
\text { participate, develop self efficacy } \\
\text { and pride around intervention } \\
\text { achievements }\end{array}$} & Uthando doll & \multirow{2}{*}{$\begin{array}{l}\text { Mothers have increased } \\
\text { understanding about how } \\
\text { children use play to } \\
\text { communicate }\end{array}$} \\
\hline & & & $\begin{array}{l}\text { Handmade ethnically } \\
\text { appropriate doll }\end{array}$ & \\
\hline & & & My care circle (custody) & \multirow{2}{*}{$\begin{array}{l}\text { Children feel valued and } \\
\text { rewarded for participation }\end{array}$} \\
\hline & & & $\begin{array}{l}\text { A4 illustrated card with } \\
\text { emergency care contact } \\
\text { information }\end{array}$ & \\
\hline
\end{tabular}

This family-centred intervention approach, like many in the literature on chronic illness, is designed to address several concurrent issues and thus remain generalisable to epidemic settings, and to have value beyond disclosure alone. Some of the more general issues addressed through the intervention approach include:

Firstly, it focuses on strengthening family relationships through a specific family engagement process, as opposed to simply providing HIV education to the mother. This is important because improvements in the quality of the parent-child and family relationship have shown particular promise in improving outcomes in children and adolescents following maternal HIV disclosure [5-7].

Secondly, we consider the context of stigma and how this may have limited initial acceptance by the mother of her own HIV infection. In many epidemic contexts mothers may have received no prior counselling, we thus offer support and education to adjust to the changes that HIV brings within the family, attempting to reduce the social isolation, stress and worries of the HIV- positive parent [53,54].

Thirdly, it aims to help family members, and parents in particular, to prevent HIV from dominating family life and sacrificing normal family or parenting goals [52,55]. Promoting parental self-efficacy is important given the possible effects of living in stigmatized communities [56].

Lastly, the intervention approach intends to provide a new structure and focus for the family which is centred on parenting and quality care for children, with adjustments of roles and expectations to ensure optimal self-care of the HIV-positive mother, care of the child and health promotion at a family level $[57,58]$.

\section{Home-based model delivered by lay counsellors}

The principles outlined above are important to the design of evidence-based family-centred HIV interventions; however, in Southern Africa public health resources are scarce and intervention approaches need to be inexpensive and feasible. In areas of high HIV prevalence clinics are overburdened, with lack of waiting areas or private rooms in which to counsel patients, and shortages of health care staff [59-61]. This intervention has, therefore, been designed to be conducted in the home setting, thus not burdening the health facilities, by lay counsellors or CHWs with no tertiary or formal health education, who will receive structured training to conduct this intervention [62]. The intervention materials were designed to achieve the goals of disclosure and to prepare the mother, emotionally, to undertake disclosure in a child-centred way. However, lay counsellors and CHWs also work in time-pressured, task-heavy, roles and compassion fatigue is commonplace [59-61]. Therefore, several of the activities, such as the My Life Line and My HIV Story exercises (see Table 1) were developed to serve the dual purpose of preparing the mother for disclosure and keeping the counsellor compassionate and attentive.

\section{Structured processes and tools that are developmentally appropriate and build skills in the mother}

This intervention targets mothers in South Africa, and a younger age group of children than most previous studies, with the exception of the TRACK program in the United States (28). Whilst there is a dearth of intervention evidence on maternal disclosure globally, there is a significant body of literature around children's understanding of illness linked to their developmental stage [63], and in particular children's developmental capacity to understand and engage with illnesses such as cancer and HIV [64]. Literature relating to maternal terminal illness, but not HIV, suggests that children benefit from being provided with illness-related information, explanations about what 
they might see and expect in the patient, reassurance that they will be looked after even in difficult circumstances; and comfort that being upset is 'allowed' and 'normal' under the circumstances $[52,65,66]$.

We also know that how the disclosure event is executed can influence the child's ability to cope with the information in the future $[5,6]$. Therefore, this intervention is designed to take a structured approach, similar to the approach of the TRACK program (28), and introduces specific guidance, training and planning for the mother towards the disclosure event, including the provision of child-friendly and developmentally appropriate learning materials for use as part of the intervention. The counsellor 'trains' the mother in a step-by-step approach, and practises with her the use of the materials and tools until she is competent and confident to use them [53]. This intervention is hinged on a strengths-based model, and counselling aims to deliver core communications to build the mothers' confidence and self-efficacy as a 'good' parent, ensuring mothers feel understood and cared about, are reminded of their resilience and achievements, understand the important role they play in their children's healthy development and have their confidence built through practising parenting skills.

\section{Evaluation and assessment}

Data are collected at baseline, including details relating to the mother's health, as the literature suggests that disclosure to children often occurs as a result of illness or hospitalisation; prior disclosure of HIV status to other adults as we expected issues related to stigma and a lack of disclosure at the family level might influence the feasibility and acceptability of this intervention; and mother's literacy in English and Zulu as illiteracy may prove a barrier to the usability of the tools. At baseline, prior HIV disclosure to any or all children within the family, as well as the mother's intentions to disclose, were not considered as inclusion or exclusion criteria as we aimed to be as inclusive as possible in this exploratory pilot study. However, detailed data were collected on prior disclosures with reasons for, and against, disclosure.

Maternal disclosure to the study child following participation in the study was collected at Visit 5. To be as inclusive as possible we considered all levels of disclosure including whether the disclosure was 'partial' (i.e. the mother explained that she has a 'virus' and what this does in her body) or 'full' (i.e. the mother explained that she has a virus called 'HIV' and what this does in her body). Openended qualitative measures around mother's perceptions of the disclosure event and the materials, the child's initial reactions to disclosure, and how the mother felt about the materials were also collected. If mothers chose not to disclose following the training, they were still encouraged to complete the health promotion and custody planning components of the intervention. Pre and post data collection, including qualitative measures, were completed for all mothers irrespective of the level of disclosure they achieved. Further data were collected at Visit 7 on whether the mother and child attended the health promotion clinic visit and their experiences of this, and whether a care plan was drawn up for the child. Data were also collected on the impact of the intervention at a family level.

\section{Pilot study}

The intervention was piloted with 24 Zulu families within the Africa Centre Demographic Surveillance Area from November to December 2010. The mothers (all HIVpositive) and children (all HIV-negative) had been part of a previous Africa Centre study and had learned of their HIV status during their pregnancy with the study child, now aged 6-10 years [67]. To be eligible for inclusion in this study mothers had to be HIV-infected at the time of the original study, to have an HIV-uninfected child, to be currently resident in the study area and to be living with the study child, and to be in reasonable physical and mental health to complete the intervention activities. Where appropriate, mothers not already on HIV treatment were referred to the local HIV treatment and care programme for medical assessment. As previously noted, baseline disclosure to children or family members and intention to disclose to children or family members was not used as part of the eligibility screening in this pilot study.

A convenience sample of 24 mothers who all lived in one geographical peri-urban area was approached to facilitate completing the pilot field work in a reasonable time frame. A list of all available mothers from this area was produced, ordered by study ID from the original study, and a consecutive series of mothers were approached by telephone and home visits until 24 mothers were enrolled. A detailed description of the characteristics of participating mothers is included in Table 2.

Three lay counsellors, with previous counselling experience and training in the Amagugu intervention, delivered the intervention over a six to eight week period. Ethics permission was granted by the Biomedical Research Ethics Committee of the University of KwaZulu-Natal. Written informed consent was obtained from each woman.

\section{Statistical analysis}

Data were entered into a specifically designed Microsoft Access database. Quantitative analyses were carried out using Stata (Version 11.2; Stata Corporation, USA); qualitative data were transcribed, translated, extensively reviewed and categorised by common thematic area.

\section{Results}

All 24 mothers approached agreed to participate, and all completed the intervention. Most women required only one session of each of the visits, however two women 
Table 2 Maternal HIV health and prior HIV disclosure experience

\begin{tabular}{|c|c|c|c|c|c|c|c|}
\hline $\begin{array}{l}\text { Study } \\
\text { number }\end{array}$ & $\begin{array}{l}\text { Maternal age at } \\
\text { study enrolment } \\
\text { (Years) }\end{array}$ & $\begin{array}{l}\text { First HIV } \\
\text { diagnosis } \\
\text { (Year) }\end{array}$ & $\begin{array}{l}\text { Currently on ART } \\
\text { (Initiation date) }\end{array}$ & $\begin{array}{l}\text { Most recent } \\
\text { CD4 count }\end{array}$ & $\begin{array}{l}\text { Participant } \\
\text { perception of } \\
\text { physical health }\end{array}$ & $\begin{array}{l}\text { Current } \\
\text { partner HIV } \\
\text { status }\end{array}$ & $\begin{array}{l}\text { Disclosed to } \\
\text { current partner }\end{array}$ \\
\hline 01 & 31 & 2003 & No & 186 & Good & HIV positive & Yes \\
\hline 02 & 48 & 2003 & No & 500 & Very good & Don't know & Yes \\
\hline 03 & 30 & 2003 & No & 707 & Excellent & Don't know & Yes \\
\hline 04 & 31 & 2004 & No & 388 & Good & HIV positive & Yes \\
\hline 05 & 29 & 2002 & Yes (May 2010) & 243 & Good & Don't know & Yes \\
\hline 06 & 31 & 2002 & No & 747 & Good & Don't know & Yes \\
\hline 07 & 27 & 2002 & Yes (July 2010) & 102 & Good & No partner & No partner \\
\hline 08 & 40 & 2003 & No & 100 & Good & HIV positive & No \\
\hline 09 & 39 & 2003 & Yes (April 2010) & 1 & Good & HIV positive & Yes \\
\hline 10 & 32 & 2002 & No & 76 & Very good & Don't know & Yes \\
\hline 11 & 27 & 2003 & No & 380 & Excellent & Don't know & No \\
\hline 12 & 37 & 2003 & No & Don't know & Good & Don't know & No \\
\hline 13 & 37 & 2003 & No & 568 & Good & Don't know & No \\
\hline 14 & 33 & 2004 & Yes (Nov 2005) & 509 & Good & Don't know & No \\
\hline 15 & 46 & 2002 & Yes (Nov 2008) & 429 & Good & HIV positive & Yes \\
\hline 16 & 41 & 2003 & No & 325 & Good & HIV negative & Yes \\
\hline 17 & 34 & 2002 & No & 500 & Excellent & No partner & No partner \\
\hline 18 & 25 & 2003 & Yes (Jan 2009) & 200 & Good & HIV negative & No \\
\hline 19 & 33 & 2004 & No & 585 & Poor & Don't know & Yes \\
\hline 20 & 39 & 2003 & No & 254 & Fair & HIV positive & Yes \\
\hline 21 & 37 & 2004 & No & 361 & Good & No partner & No partner \\
\hline 22 & 24 & 2002 & Yes (Jan 2006) & 560 & Poor & HIV positive & Yes \\
\hline 23 & 41 & 2003 & Yes (Jan 2009) & Don't know & Good & HIV positive & Yes \\
\hline 24 & 34 & 2002 & Yes (May 2009) & 214 & Good & Don't know & Yes \\
\hline
\end{tabular}

repeated Visit 2 (where the mother relates her life and HIV stories) on the suggestion of the counsellor who felt they needed more counselling to work through personal issues before engaging in the intervention training. One mother repeated Visit 4 (where the mother practises the intervention tools she will use with her child), because she requested further opportunities to practise with the counsellor to build her confidence. Seventeen women were literate in both English and Zulu, six were literate in Zulu only and one participant was illiterate. The illiterate participant expressed no reservations about proceeding with the intervention and elicited assistance from a literate family member to assist with reading where required.

Data relating to self-reported health status of mothers is shown in Table 2. The mean age of mothers was 33.5 (median 32; range 24-46) years, most women were living healthily with CD4 counts above 300 (mean 339; median 361; range 1-747) while 9 women had initiated ART (current eligibility for ART in South Africa is a CD4 count of $<350$ cells $/ \mathrm{ml}$ ). Of the 24 women, 20 reported being unemployed; six received a regular remittance; 23 received a government child support grant; and 11 reported that the child's father was financially contributing towards the study child's care. Most (19) women reported being unmarried but in a relationship with a long-term partner. In 18 cases the father of the study child was still alive, and eight of the mothers were still in a relationship and living with him. A further two were living with new partners while 14 were living on their own with their children and/ or other family members. Fifteen of the 24 women had disclosed their HIV status to their current partner, 12 to a parent and a sibling and 10 to adult friends outside the household. Only three had not disclosed to any other adult, all three of whom were living with a new partner who was unaware of their HIV status. None of these three women had initiated ART and their last CD4 counts were 568,380 and 200 cells $/ \mathrm{ml}$ respectively.

The mean age of the 24 children was 6.8 (median 7; range 6-8) years, with a similar numbers of males (13) and females (11) (Table 3). Three children were currently in Grade R (pre-school year); 11 in Grade 1 (first year primary school); seven in Grade 2 (second year primary 
school); two in Grade 3 (third year primary school); data were missing for one child.

Five mothers indicated that they had either 'partially or fully disclosed' to their children prior to this intervention, mostly driven by pragmatic reasons following an illness and a need to ensure child care. In all five cases the mothers had fully disclosed (i.e. used the words "HIV") to their older children (10-18 years), but had told their younger children $(<10$ years $)$ that they had an illness which required them to go to hospital. While HIV was spoken about with older children and other family members, and it was possible the younger children were aware of, or had heard about HIV, in the family, in these five cases the mothers were unsure what the younger child knew and understood about HIV at baseline. As a result, all five of these mothers wished to participate in this intervention to disclose fully to the younger index child, as they felt their previous partial disclosures around illness and hospitalisations had been inadequate. These mothers were considered to have a clear intention to disclose at the start of the intervention. Of the remaining 19 women, three had disclosed fully to an older child but had made no disclosure to the younger index child while 16 had not disclosed to any of their children regardless of their age. None of these 19 mothers expressed any intention to disclose to the index child prior to enrolling in the study.

The most salient concerns about disclosure prior to the disclosure intervention were that the child was too young (22/24), might suffer emotionally afterwards (21/24), would disclose to others $(21 / 24)$ or that the mother felt unable to answer difficult questions relating to the source of the HIV infection or death $(19 / 24)$.

All 24 mothers chose to disclose something about their illness to their children during the intervention, but levels of HIV disclosure differed. Almost half the mothers (11) disclosed fully using the words "HIV" and indicating to the child that they were infected with HIV, while the remaining 13 disclosed partially, explaining that they had a virus, and using the tools to explain what the virus did in their bodies and how it can be controlled, without specifically using the words "HIV". Among the 19 mothers who had not disclosed previously, and had no intention to disclose at the start of the intervention, 8/19 fully disclosed using the words 'HIV' while 11/19 chose to undertake partial disclosure. In two cases indicated by "in Table 3 (Family Study Numbers 20 and 21), the mother disclosed using the words "Virus" during the disclosure activity, but the child subsequently began asking questions about "AIDS" in the case of Family 20 and directly asked for the virus name in the case of Family 21. In Family 21 the mother did not name "HIV" while in Family 20 the mother shifted to discussing HIV openly. In both these cases the maternal disclosure is listed as partial as this most closely reflects the mothers' intention and action during the intervention disclosure. However, in these two cases it is clear that for one child (Family 20) significant knowledge of HIV may have preceded the intervention, and for the other (Family 21) when the mother was presented with an option to disclose more fully she continued with partial disclosure. It is noteworthy that of the $5 / 11$ mothers who stated they had disclosed fully to older children prior to the intervention and intended to disclose fully to younger children as part of the intervention, only $2 / 5$ subsequently disclosed fully and reported their children were calm (Family 8 and 15); the remaining $3 / 5$ chose to disclose partially. Unlike in Family 20, in Families 23 and 24 the children's questions following partial disclosure did not indicate any knowledge of HIV or willingness to raise questions about HIV in response to the partial disclosure.

Most mothers described the reaction of their children to the disclosure intervention as calm, accepting and confident (14), eight reported that their child was initially confused and in need of further explanation, and only two reported fear or emotional distress as the initial reaction to disclosure. Table 3 summarises children's reactions, commonly asked questions after disclosure and mothers' experiences of undertaking disclosure using the intervention materials. A few mothers (6/24) reported that there were aspects of disclosure that they did not enjoy, including: feeling frustrated that the child did not understand initially, feeling disappointed that the child had not asked more questions, feeling concerned that knowing about her HIV status was hurtful for the child and caused emotional distress, finding it difficult to talk openly about HIV, and feeling nervous about using the HIV Body Map and saying the words "HIV" out loud. Two mothers reported not enjoying the Family Life Line exercise (Session 4, Table 1), the first because it brought up difficult issues around stepsiblings in the household who were raised by the current partner, and the other because it raised difficult issues about bereavement and people who had died which she felt ill-prepared for. The most salient challenge raised by mothers in the post-disclosure interview was finding a quiet space in the home to undertake disclosure, with many mothers reporting having to deal with interruptions by younger children who wanted to play with the intervention materials.

While family members were encouraged to participate in the intervention, only a few (3/24) helped the mother with practice and preparation, two of whom subsequently participated in the disclosure event with the mother. However, more family members became involved in health promotion and custody planning activities following the disclosure being completed by the mother. Four mothers reported challenges in taking their children to clinic as they were employed: in two cases the father of the child completed the clinic 
Table 3 Maternal disclosure to HIV-negative children

\begin{tabular}{|c|c|c|c|c|c|c|c|}
\hline ID & Sex & Age & $\begin{array}{c}\text { Prior } \\
\text { disclosure }\end{array}$ & $\begin{array}{l}\text { Intervention } \\
\text { disclosure }\end{array}$ & $\begin{array}{l}\text { Mother report of } \\
\text { child's reaction } \\
\text { to disclosure }\end{array}$ & $\begin{array}{l}\text { Mother reported questions } \\
\text { asked by child following } \\
\text { disclosure }\end{array}$ & $\begin{array}{l}\text { Mother reported what she } \\
\text { enjoyed most about } \\
\text { disclosure }\end{array}$ \\
\hline 01 & M & 6 & No & Virus & Confused & $\begin{array}{l}\text { How did you get infected; I } \\
\text { haven't seen you go to clinic, } \\
\text { when do you go to clinic? What } \\
\text { do the nurses and doctors do at } \\
\text { clinic? }\end{array}$ & $\begin{array}{l}\text { I really enjoyed the questions } \\
\text { the child asked me }\end{array}$ \\
\hline 02 & M & 7 & No & HIV & $\begin{array}{l}\text { Frightened } \\
\text { Emotional }\end{array}$ & $\begin{array}{l}\text { Will I get HIV; how can I be safe } \\
\text { from HIV? }\end{array}$ & $\begin{array}{l}\text { I enjoyed the peace that I felt } \\
\text { after }\end{array}$ \\
\hline 03 & $\mathrm{~F}$ & 6 & No & HIV & Confused & $\begin{array}{l}\text { What is HIV and what should you } \\
\text { be doing at clinic about it? }\end{array}$ & $\begin{array}{l}\text { I enjoyed the materials, } \\
\text { because they are so positive } \\
\text { about me, even when I am } \\
\text { getting sick, I can give them } \\
\text { love, the messages are good }\end{array}$ \\
\hline 04 & $\mathrm{~F}$ & 6 & No & Virus & Calm & $\begin{array}{l}\text { Does a person with this virus } \\
\text { become very slim? }\end{array}$ & $\begin{array}{l}\text { I enjoyed that she seemed to } \\
\text { understand, like she } \\
\text { understands that a person } \\
\text { with HIV does not have AIDS }\end{array}$ \\
\hline 05 & $\mathrm{~F}$ & 8 & No & Virus & Confused & $\begin{array}{l}\text { How did you get the infection? } \\
\text { When can I go to clinic? }\end{array}$ & $\begin{array}{l}\text { I enjoyed that the child asked } \\
\text { questions I could answer }\end{array}$ \\
\hline 06 & M & 8 & No & Virus & Calm & No question & $\begin{array}{l}\text { I enjoyed playing cards with } \\
\text { the child }\end{array}$ \\
\hline 07 & $F$ & 7 & No & HIV & Confused & $\begin{array}{l}\text { Is this what caused my dad to } \\
\text { die?; is this why we can't visit } \\
\text { dad's family anymore? }\end{array}$ & $\begin{array}{l}\text { I enjoyed most going } \\
\text { through our family life line }\end{array}$ \\
\hline 08 & M & 6 & Yes & HIV & Calm & No question & $\begin{array}{l}\text { I enjoyed every moment of it } \\
\text { and that he is the first of my } \\
\text { children to know the truth, } \\
\text { and I know he is going to } \\
\text { come back and ask me about } \\
\text { the father soon, then it will } \\
\text { all be open }\end{array}$ \\
\hline 09 & M & 7 & No & HIV & Confused & $\begin{array}{l}\text { What is that lion doing in the } \\
\text { house with the people in the } \\
\text { storybook? }\end{array}$ & $\begin{array}{l}\text { The joy that the storybook } \\
\text { brought for the child is what } \\
\text { I most enjoyed and I enjoyed } \\
\text { being able to give a deep } \\
\text { explanation of HIV }\end{array}$ \\
\hline 10 & $\mathrm{~F}$ & 8 & No & HIV & Calm & No question & $\begin{array}{l}\text { I enjoyed that my child learnt } \\
\text { that if a person is sick they } \\
\text { will get help from the clinic }\end{array}$ \\
\hline 11 & M & 7 & No & HIV & Calm & $\begin{array}{l}\text { Are you going to die; Is HIV } \\
\text { curable? }\end{array}$ & $\begin{array}{l}\text { I enjoyed that I was the one } \\
\text { who was able to teach him } \\
\text { and that he understood it all }\end{array}$ \\
\hline 12 & M & 7 & No & HIV & Calm & No question & $\begin{array}{l}\text { The fact that my child } \\
\text { understood and we had a } \\
\text { chance to talk }\end{array}$ \\
\hline 13 & $\mathrm{~F}$ & 6 & No & HIV & Calm & No question & $\begin{array}{l}\text { I enjoyed all the disclosure } \\
\text { steps, they impressed me a } \\
\text { lot }\end{array}$ \\
\hline 14 & $F$ & 6 & No & HIV & Calm & $\begin{array}{l}\text { Why do you have to take pills } \\
\text { always? }\end{array}$ & $\begin{array}{l}\text { I enjoyed all the steps and I } \\
\text { feel more confident to talk } \\
\text { about my illness now }\end{array}$ \\
\hline 15 & F & 8 & Yes & HIV & Calm & $\begin{array}{l}\text { Is this what happened to my } \\
\text { father? Did you love my father? } \\
\text { How did you get the HIV, did } \\
\text { you get it from my father or } \\
\text { another man? Would my father } \\
\text { be alive if he took medicine? }\end{array}$ & $\begin{array}{l}\text { I really enjoyed everything } \\
\text { about doing disclosure }\end{array}$ \\
\hline
\end{tabular}


Table 3 Maternal disclosure to HIV-negative children (Continued)

\begin{tabular}{|c|c|c|c|c|c|c|c|}
\hline 16 & M & 7 & No & Virus & Calm Frightened & No question & $\begin{array}{l}\text { I enjoyed the whole thing } \\
\text { from the beginning to the } \\
\text { end }\end{array}$ \\
\hline 17 & M & 8 & No & Virus & Confused & $\begin{array}{l}\text { Do all viruses kill people? Are } \\
\text { you going to die from the virus? } \\
\text { Will I be left with no parents? }\end{array}$ & $\begin{array}{l}\text { I enjoyed that my child was } \\
\text { interested and listened to me }\end{array}$ \\
\hline 18 & M & 7 & No & Virus & Calm & $\begin{array}{l}\text { Does my niece who takes pills } \\
\text { have this Virus also? }\end{array}$ & $\begin{array}{l}\text { Telling him was important for } \\
\text { him to know, it was exciting } \\
\text { and I felt good, I felt at peace } \\
\text { for no longer keeping it from } \\
\text { him }\end{array}$ \\
\hline 19 & M & 6 & No & Virus & Calm Confused & $\begin{array}{l}\text { Do I have a virus now? Should I } \\
\text { eat more vegetables? }\end{array}$ & $\begin{array}{l}\text { I enjoyed our talk, and it } \\
\text { brought back hope to me as } \\
\text { I was talking to him }\end{array}$ \\
\hline 20 & M & 6 & Yes & Virus* & Calm & $\begin{array}{l}\text { What is AIDS, is it the same as a } \\
\text { virus? Does my stepfather have } \\
\text { it? Did my father have it before } \\
\text { he died; Are ARVs the same as } \\
\text { the tablets you showed me on } \\
\text { the body map? Does AIDS ever } \\
\text { get finished in the body? }\end{array}$ & $\begin{array}{l}\text { I enjoyed and I like the fact } \\
\text { that he was so quick to } \\
\text { understand, he is clever }\end{array}$ \\
\hline 21 & $\mathrm{~F}$ & 6 & No & Virus* & Calm & What is this virus called? & $\begin{array}{l}\text { I enjoyed using all the } \\
\text { materials }\end{array}$ \\
\hline 22 & M & 7 & No & Virus & Calm & No question & $\begin{array}{l}\text { I enjoyed most that my child } \\
\text { understood most of what we } \\
\text { did, I wasn't expecting it }\end{array}$ \\
\hline 23 & $\mathrm{~F}$ & 7 & Yes & Virus & Calm Confused & No question & $\begin{array}{l}\text { I enjoyed having a chance to } \\
\text { talk about my status }\end{array}$ \\
\hline 24 & $\mathrm{~F}$ & 7 & Yes & Virus & Calm & No question & $\begin{array}{l}\text { I enjoy the materials because } \\
\text { of the good messages it } \\
\text { brings to me and my } \\
\text { children }\end{array}$ \\
\hline
\end{tabular}

*In cases where mother undertook disclosure using words Virus and child's questions led to a discussion on HIV or AIDS using those words, disclosure is listed as partial given that mother-led disclosure was initially partial.

component of the intervention, and in the remaining two an older sibling accompanied the child to the clinic.

\section{Mothers perceptions of the intervention and materials}

Prior to the intervention mothers expressed concerns about disclosure including fears that the child might raise issues about HIV and death:

"They can be full of fear that I may die anytime soon"

concerns that the child was too young to understand:

"She is still too young and not clever enough to understand"

worries that the disclosure would cause the child emotional damage:

"I felt that they would not accept it, they would get frustrated and not do well at school" and fears that the child would tell others about her HIV status:

"My child talks too much, she may tell other people"

However, the materials, illustrations and branding reinforced maternal confidence to disclose their HIV status, improving maternal self-efficacy:

"I was so nervous about the telling, saying the words, but now I see how the body map works, I can just show the child and take myself there easy"

"I feel like this is going to be very useful in showing me how to do it well for my child"

providing confidence around the quality of the materials:

"The children will feel too excited because it looks like it came from the shops" 
making the disclosure process seem more realistic and approachable:

"These materials makes disclosure less scary for me"

helping the mother to organise her thoughts in a structured way:

"The steps are easy to understand, in the way that they are presented, I will enjoy to use it, I can't easily get lost"

and giving a structure for explaining health related issues:

"I really like the materials, I have been struggling to explain to my children about clinic, why I take the pills, and they have not understood clearly, with these materials even I understand more clearly"

"This body map makes a real contribution I can use it to explain so many things from HIV to even the flu"

For most mothers in the intervention, the materials (see Table 1) were the first of their kind in the household. Only seven households reported having any storybook in the household prior to the intervention and 22 reported that the story book helped them to spend more time with the child. All women expressed the desire for access to similar books covering topics including: Teaching children to be safe from child sexual abuse; Teaching young children about their bodies and sex education; Teaching morals and values and good behaviour. Similarly, only nine mothers reported that any of their children had a doll prior to the intervention, and most felt it was a useful 'play and communication' tool, reminding them to play with their child (18), helping them to listen to their child (19) and understand their child's worries better (18), and recognising what makes their child feel happy and reassured (17).

\section{Counsellors' perceptions of the intervention and materials}

An important aspect of the intervention development was ensuring that the structure of the materials assisted the counsellor to focus on the mothers' emotional issues. The counsellors reported finding the tools useful in containing emotions and organising narratives, and maintaining counsellor empathy with the mother:

"It was so simple now that we are doing it, the different steps you do, first it is listening and it's even a surprise to the person them self. . .they think you just want to know about them being HIV-infected....then they are surprised you actually want to know their love stories, it's a good surprise, everything about their face and body changes, because they see I am looking at them and that I see them and not the HIV positive label" [Counsellor 1]

"It helps that we talk and then do a timeline, it helps to bring the story together, to make sense of things, it becomes that you are looking at it together, so you start to feel you get a same view, like you are both looking out the same window" [Counsellor 2]

"Asking mothers to tell their love stories as part of their life stories, well it's different to what I expected, you learn to be humble about yourself, we all make mistakes in love, you don't have to make many or even big mistakes before you can get HIV, when you take people back in time they have a chance to explain, you are saying to them that you are there to help, you are a real person who knows the real world, and you want to deal with real life" [Counsellor 3]

Quality assurance (QA) visits were conducted by a masters level project coordinator with a randomly selected sample of $10 \%$ of visits and counsellors scored $>80 \%$ on all QA visits for all sessions. Each session included a rating scale covering core concepts and step fidelity; raw scores were converted to percentages and averaged over sessions by counsellor. Failures on QA most commonly related to fidelity in the order, rather than omission, of steps in particular intervention sessions. On average, the individual and family preparation phase of the intervention required 1-2 counsellor hours (Session 1 and 2), disclosure training took 2-3 hours (Session 3 and 4), health promotion training 1-2 hours (Session 5). Mothers reported that on average the disclosure process took less than one hour with the child; all mothers completed the intervention within an 8 week period.

\section{Community perceptions of the intervention and materials}

Finally, ensuring cultural sensitivity in the development of the illustrations was important in the piloting of the materials:

"... to see those illustrations and the stories and stuff, I mean, you know, as a Zulu person out there in the world you just don't see that happening, to have something that looks like you, not like a cartoon with black coloured skin or those stupid things you know, but that really looks like you, your culture, the colours, your hair; the way people dress, you just don't see things like that, you don't really even think that you haven't seen them until you see them and then you say 'hey look at this - this is really cool, why haven't I seen 
this before now, I'm a Zulu person and this looks like me, this looks like my family, you know what I mean, it's really cool and it counts for a lot, and it says something about who you are and how you want to help and respect people in this community." [Member of the Africa Centre Community Liaison Office]

\section{Children's reactions to disclosure}

After the disclosure, the questions children asked of their mothers were similar to those commonly cited in the literature, relating mainly to the nature of HIV, transmission and HIV medication (Table 3). Several children sought reassurance that they were not infected themselves and that the mother was not going to die soon. An unusual finding related to the level of inadvertent disclosure of siblings' and other adults' HIV status that occurred as a result of maternal disclosure and discussion of HIV-related issues (see children's questions in Table 3).

\section{The intervention impact on family relationships, health promotion and care planning}

As shown in Table 4, mothers perceived that this intervention resulted in improvements in family relationships and understanding of roles and responsibilities towards child care, increased health promotion activities in the homestead and improved parent confidence around health promotion and sex education, increased discussion around child protection risks including bullying, teacher problems, physical and sexual abuse. At the post-intervention interview, 6 of the 24 mothers reported that, as a result of the intervention, they had disclosed to an adult family member whom they had not disclosed to previously, suggesting that the intervention may increase disclosure more generally in the family. While the intervention resulted in these changes within the home environment and family relationship, the same increases in confidence were not evidenced in maternal confidence to effect change in their broader community.

\section{Discussion}

This pilot study with 24 families showed high levels of acceptability and encouraging results in terms of effectiveness as defined by mothers undertaking full or partial disclosure. Almost half the mothers who had never previously disclosed to a child in the family, disclosed to a child aged 6-10 years making a full disclosure using the words 'HIV' as part of this intervention. Participation and disclosure rates suggest the intervention package is culturally acceptable and there appear to be no major barriers to intervention support using this family-centred model. Thus, the intervention shows promise for supporting maternal HIV disclosure in rural HIV endemic settings in Southern Africa.
Our data suggest that decisions around disclosure are complex, and the choice to make a full or partial disclosure may be dependent on several factors. The small sample size in this pilot prevents any meaningful analysis of factors associated with the choice to make a full or partial disclosure, for example child age or gender.

It is possible that the younger age of most children in this sample may have influenced mothers' preference for partial disclosure, but it is also possible that the preference for partial disclosure was influenced by other factors such as the mothers' personal readiness or household factors not captured in the pilot. Further research is required to better understand these decisions and how disclosure intentions of mothers prior to the intervention influence whether or how much they disclose to their children.

While these findings are preliminary and should be interpreted with caution, they are encouraging. The intervention is innovative in that it targets a young age group in a high HIV prevalence area. To our knowledge this is the first intervention targeting primary school-age children (6-10 years) from a resource-limited setting, with the intervention messages focusing not only on HIV disclosure itself but also on health promotion for pre-adolescent children. As in the TRACK program [28], we focus on the 'relationship context' and improving parenting skills [68], which have been associated with decreased child problem behaviours $[28,53,55]$. However, our intervention is somewhat more intensive, involving six as opposed to three home visits, is more directive and supplemented in each session with illustrated materials and games to help mothers facilitate disclosure and to assist lay counsellors to focus on the topic. This increased intensity, structure and the strength of the counselling relationship may explain the positive disclosure rates. It is not appropriate to compare these results to the TRACK program which reported post intervention disclosure rates of $33 \%$ in the intervention group and $7 \%$ in the control given that the TRACK program only enrolled mothers with no intention to disclose. However, in light of generally low disclosure rates around the world, achieving close to fifty percent full HIV disclosure in this pilot study, using a locally adapted, similar approach to other international studies shows promise for future work in this area. Further research is required to test whether these findings are replicable and the intervention feasible at a larger scale. A larger demonstration project which aims to enrol 300 families is currently underway.

While the intervention was highly directive and structured, feedback from mothers and counsellors suggests that an important intervention component was the focus on counselling, and training the mother to achieve competence to intervene with her own children as opposed to study counsellors directly intervening with children. This was highly acceptable to both counsellors and mothers and 
Table 4 Intervention impact on family support, health promotion, maternal confidence and child protection (Questions asked to the mother)

\begin{tabular}{|c|c|c|c|}
\hline \multicolumn{4}{|l|}{ Family support } \\
\hline As a result of the family support activities do you believe: & $\begin{array}{l}\text { Mothers } \\
\text { agree }\end{array}$ & $\begin{array}{l}\text { Mothers } \\
\text { disagree }\end{array}$ & $\begin{array}{l}\text { Don't } \\
\text { know }\end{array}$ \\
\hline The child is able to identify who can support and care for them in the family (more than in the past) & 20 & 2 & 2 \\
\hline The family feels it is clear that they are responsible for the care of the child (more than in the past) & 21 & 0 & 3 \\
\hline I feel more supported and cared for in my role as a parent by my family members & 22 & 0 & 2 \\
\hline I feel less anxious about the future care of my child or children if something happens to me & 22 & 0 & 2 \\
\hline \multicolumn{4}{|l|}{ Health promotion } \\
\hline Following the intervention have you continued to use the materials & Not at all & A few times & Everyday \\
\hline In the last week how many times have you or your child used the body map with anybody in your family? & 7 & 11 & 6 \\
\hline $\begin{array}{l}\text { In the last week how many times have you or your child used the health promotion playing cards with } \\
\text { anybody in your family? }\end{array}$ & 13 & 10 & 1 \\
\hline Thinking about the body map and how it was used in this intervention: & Yes & No & $\begin{array}{l}\text { Don't } \\
\text { know }\end{array}$ \\
\hline Could you use it to teach about other health issues in the future & 21 & 2 & 1 \\
\hline Could you use it for sex education in the future & 21 & 0 & 3 \\
\hline \multicolumn{4}{|l|}{ Maternal confidence } \\
\hline Given what you have learnt in this intervention, would you feel confident to: & Yes & No & $\begin{array}{l}\text { Don't } \\
\text { know }\end{array}$ \\
\hline Help other HIV positive mothers in your community to talk about disclosure with their children & 8 & 2 & 14 \\
\hline Help community stakeholders understand how to talk about disclosure with their children & 9 & 0 & 15 \\
\hline Advocate for yourself and your child's health rights at the clinic and share what you know about disclosure & 9 & 0 & 15 \\
\hline \multicolumn{4}{|l|}{ Child protection } \\
\hline Before this intervention, had you or anyone in your family ever talked with your child about: & Yes & No & Missing \\
\hline Risks of bullying from friends & 11 & 13 & 0 \\
\hline Teacher-child problems & 8 & 16 & 0 \\
\hline Physical abuse & 10 & 14 & 0 \\
\hline Sexual abuse & 7 & 17 & 0 \\
\hline \multicolumn{4}{|l|}{ As a result of the intervention did you talk with your child about: } \\
\hline Risks of bullying from friends & 19 & 3 & 2 \\
\hline Teacher-child problems & 19 & 3 & 2 \\
\hline Physical abuse & 18 & 4 & 1 \\
\hline Sexual abuse & 14 & 8 & 2 \\
\hline
\end{tabular}

likely accounts for reported improvements in maternal confidence to deal with HIV and health-related matters in the family.

Importantly, this intervention was conducted by lay counsellors, who were able to learn to use the materials and deliver the intervention with this pilot group of mothers. This is particularly important for later scale-up given the increasing time constraints on professional health staff within HIV programmes. Task shifting is already taking place in many areas of health care in subSaharan Africa, with lay counsellors or CHWs taking on roles in infant feeding counselling, HIV counselling, ART adherence, and nutrition counselling [69,70]. Lay counsellors and CHWs have shown ability to conduct psycho-social interventions at the primary health care level, including HIV counselling, testing, and training to initiate HIV treatment [71] and to deliver simplified psychological interventions in poorly resourced settings [72,73]. Further, the South African National Department of Health plans to include community health care workers as key players in the new primary health care teams, which will focus particularly on improving maternal and child health outcomes [61].

However, little intervention research has focused on the development of techniques, activities and guidelines to train lay counsellors or CHWs to deliver psychologically complex interventions in Southern Africa. To address this, our intervention approach considered several common factors known to impact on therapeutic outcomes [74]. The intervention specifically focused on integrating 
structured counsellor activities to increase counsellor empathy, positive unconditional regard, and to facilitate encouragement and acknowledgment of achievements by the mother. Such factors are known as 'therapeutic variables', and have been shown to account for at least a third of positive outcomes in psychotherapy [75] and social work [76]. It is possible that a similar intervention approach could be applied to a variety of topic areas addressing challenges that HIV-positive parents and families face.

Besides 'therapeutic variables' we considered 'extra therapeutic variables' known to contribute to positive outcomes in therapeutic relationships, including increasing maternal support in the home and the health care system [75]. The intervention successfully draws on and adapts established therapeutic techniques and processes (from psychotherapy, family and cognitive behavioural therapy) into a structured intervention which facilitates the enactment of therapeutic techniques by a lay counsellor. Counsellors found the materials user-friendly, and quality assurance data suggests that the materials assisted in ensuring a high level of intervention fidelity, which has been shown to be a challenge in family HIV interventions [35].

In line with the international literature [7,33], the qualitative data suggests that mothers had significant distress around disclosure of their own HIV status to their children and felt unable to approach the topic without intervention support. In particular, the qualitative data from participating mothers suggests that these investments in material design and culturally-sensitive illustrations have proved critical to reinforcing maternal self-efficacy. Investing in high quality, age-appropriate and attractively designed materials communicates value and respect, reinforces positive attributes and inspires confidence in HIV disclosure, helping the mother and counsellor to organise their thoughts around the disclosure process. Children's questions were fairly predictable and the counsellor and mother had worked through these questions and some possible ways to answer them in Visit 4.

\section{Conclusion}

In summary this intervention illustrates that complex therapeutic processes can be transformed into practical, structured, step-by-step activities that encourage both experiential learning and reflective practice, and bring about health behaviour change at a familial level. There are several limitations to this study, most importantly it is a small pilot study, and the sample size does not allow for wide generalisation of the findings. Furthermore, given the convenience sampling strategy and lack of a control group it is possible that the results are influenced by selection bias. Further research is required to test these results in a larger sample and a controlled study, to determine the factors that influence the degree of maternal disclosure, and the impact this disclosure has for mothers, children and families over time.

\section{Endnotes}

"Amagugu is a Zulu term meaning "Treasures" to capture the concept that children are our future and are precious.

${ }^{\mathrm{b}}$ For information on play for communication see www. dlalanathi.org.za and www.uthandoproject.org.

\section{Competing interests}

We declare no competing interests. This study was funded by the Canadian International Development Agency (CIDA). Ruth Bland and Tamsen Rochat received salary support from the Wellcome Trust-funded Africa Centre. Tamsen Rochat and Ntombizodumo Mkwanazi also received salary support from CIDA.

\section{Authors' contributions}

TR contributed to the design and development of the intervention, assisted in securing funding and ethical permissions for the research, provided oversight of data collection and data entry and was responsible for data analysis and interpretation, and the initial draft and further revisions of the manuscript. NM participated in the development of intervention materials and the training and oversight of intervention staff; she was responsible for the collection and entry of data during the pilot study and assisted with data cleaning and interpretation of the results. She assisted with literature searches and referencing on the initial draft of the manuscript and contributed to critical revisions of the revised manuscript. RB led the design and development of the intervention, was responsible for securing funding and ethical permissions for the research, provided oversight of data analysis and interpretation of results, and provided significant input into both the initial draft and further critical revisions of the manuscript. All authors read and approved the final manuscript.

\section{Acknowledgements}

We thank the Amagugu field and office team including Samu Dube, Bonnie Gumede, Hlengiwe Mtolo, and Philani Sithole; Colin Newell for database design and management; Alan Stein for scientific input; the Africa Centre Community Liaison Officer and Community Advisory Board; and the mothers and families who agreed to take part in the Amagugu intervention.

\section{Author details}

${ }^{1}$ Africa Centre for Health and Population Studies, University of KwaZulu-Natal, Mtubatuba, South Africa, and Department of Psychology, Stellenbosch University, Stellenbosch, South Africa. ${ }^{2}$ Africa Centre for Health and Population Studies, University of KwaZulu-Natal, Mtubatuba, South Africa, and School of Public Health, University of Witwatersrand, Johannesburg, South Africa. ${ }^{3}$ Africa Centre for Health and Population Studies, University of KwaZulu-Natal, Mtubatuba, South Africa; School of Medicine, University of Glasgow, Glasgow, United Kingdom, and School of Public Health, University of Witwatersrand, Johannesburg, South Africa.

Received: 22 October 2012 Accepted: 8 February 2013

Published: 18 February 2013

\section{References}

1. UNAIDS: Global Report: UNAIDS report on the global AIDS Epidemic 2010. New York: UNAIDS; 2010.

2. MCNally LM, Hadingham J, Archary D, Moodley R, Coovadia HM: HIVexposed but uninfected children: why are they vulnerable? Vulnerable Children and Youth Studies 2006, 1(2):139-148.

3. Grimwood A, Fatti G, Mothibi E, Eley B, Jackson D: Progress of preventing mother-to-child transmission of HIV at primary healthcare facilities and district hospitals in three South African provinces. SAMJ: South African Medical Journal 2012, 102(2):81-83.

4. Filteau S: The HIV-exposed uninfected African child. Trop Med Int Health 2009, 14(3):276-287.

5. Hawk ST: Disclosures of maternal HIV infection to seronegative children: a literature review. J Soc Pers Relat 2007, 24(5):657-673. 
6. Murphy DA: HIV-positive mothers' disclosure of their serostatus to their young children: a review. Clin Child Psychol Psychiatry 2008, 13(1):105-122.

7. Qiao S, Li X, Stanton B: Disclosure of Parental HIV Infection to Children: A Systematic Review of Global Literature. AIDS Behav 2013, 17(1):369-89.

8. Letteney S: Mothers disclosure of maternal HIV status to children. Journal of HIV/AIDS \& Social Services 2006, 5(1):67-84.

9. Murphy DA, Marelich WD, Amaro H: Maternal HIV/AIDS and adolescent depression: a covariance structure analysis of the 'Parents and Children Coping Together' (PACT) Model. Vulnerable Children and Youth Studies 2009, 4(1):67-82.

10. Vallerand AH, Hough E, Pittiglio L, Marvicsin D: The process of disclosing HIV serostatus between HIV-positive mothers and their HIV-negative children. AIDS Patient Care STDS 2005, 19(2):100-109.

11. Armistead L, Tannenbaum L, Forehand R, Morse E, Morse P: Disclosing HIV status: are mothers telling their children? J Pediatr Psychol 2001, 26(1):11-20

12. Delaney RO, Serovich JM, Lim J-Y: Psychological differences between HIVpositive mothers who disclose to all, some, or none of their biological children. J Marital Fam Ther 2009, 35(2):175-180.

13. Rotheram-Borus MJ, Draimin BH, Reid HM, Murphy DA: The impact of illness disclosure and custody plans on adolescents whose parents live with AIDS. AIDS 1997, 11(9):1159-1164.

14. Wiener LS, Battles HB, Heilman NE: Factors associated with parents' decision to disclose their HIV diagnosis to their children. Child Welfare 1998, 77(2):115-135.

15. Pilowsky D, Sohler N, Susser E: Reasons given for disclosure of maternal HIV status to children. J Urban Health 2000, 77(4):723-734.

16. Simoni JM, Davis ML, Drossman JA, Weinberg BA: Mothers with HIV/AIDS and their children: disclosure and guardianship issues. Women Health 2000, 31(1):39-54.

17. Murphy DA, Steers WN, Dello Stritto ME: Maternal disclosure of mothers' HIV serostatus to their young children. J Fam Psychol 2001, 15(3):441-450.

18. Corona R, Beckett MK, Cowgill BO, Elliott MN, Murphy DA, Zhou AJ, Schuster MA: Do children know their Parent's HIV status? Parental reports of child awareness in a nationally representative sample. Ambul Pediatr 2006, 6(3):138-144.

19. Palin F, Armistead L, Clayton A, Ketchen B, Lindner G, Kokot-Louw P, Pauw A: Disclosure of maternal HIV-infection in South Africa: description and relationship to child functioning. AIDS Behav 2009, 13(6):1241-1252.

20. Armistead L, Klein K, Forehand R, Wierson M: Disclosure of parental HIV infection to children in the families of men with hemophilia: description, outcomes, and the role of family processes. J Fam Psychol 1997, 11(1):49-61.

21. Dematteo D, Harrison C, Arneson C, Goldie RS, Lefebvre A, Read SE, King SM: Disclosing HIV/AIDS to children: the paths families take to truthtelling. Psychol Health Med 2002, 7(3):339-356.

22. Lee MB, Rotheram-Borus MJ: Parents' disclosure of HIV to their children. AIDS 2002, 16(16):2201-2207.

23. Thorne C, Newell ML, Peckham CS: Disclosure of diagnosis and planning for the future in HIV-affected families in Europe. Child Care Health Dev 2000, 26(1):29-40.

24. Hosegood V: Madhavan: data availability on men's involvement in families in sub-Saharan Africa to inform family-centred programmes for children affected by HIV and AIDS. J Int AIDS Soc 2010, 13(Suppl 2):S5.

25. Armistead L, Morse E, Forehand R, Morse P, Clark L: African-American women and self-disclosure of HIV infection: rates, predictors, and relationship to depressive symptomatology. AIDS Behav 1999, 3(3):195-204.

26. Bauman LJC S, Silver EJ, Hudis J, Draimin B: Behavioural problems in school-aged children of mothers with HIV/AIDS. Clin Child Psychol Psychiatry 2002, 7(39):39-54.

27. Shaffer A, Jones DJ, Kotchick BA, Forehand R: Telling the children: disclosure of maternal hiv infection and its effects on child psychosocial adjustment. Journal of Child and Family Studies 2001, 10(3):301-313.

28. Murphy DA, Armistead L, Marelich WD, Payne DL, Herbeck DM: Pilot trial of a disclosure intervention for HIV + Mothers: the TRACK program. J Consult Clin Psychol 2011, 79(2):203-214.

29. Nöstlinger $C$, Jonckheer $T$, de Belder $E$, van Wijngaerden $E$, Wylock $C$ Pelgrom J, Colebunders R: Families affected by HIV: parents' and children's characteristics and disclosure to the children. AIDS Care 2004, 16(5):641-648

30. Xu T, Yan Z, Rou K, Wang C, Ye R, Duan S, Wu Z: Disclosure of parental HIV/AIDS to children in rural China. Vulnerable Children and Youth Studies 2007, 2(2):100-105
31. Nam SL, Fielding K, Avalos A, Gaolathe T, Dickinson D, Geissler PW Discussing matters of sexual health with children: what issues relating to disclosure of parental HIV status reveal. AIDS Care 2009, 21(3):389-395.

32. Rwemisisi J, Wolff B, Coutinho A, Grosskurth H, Whitworth J: 'What if they ask how I got it?' Dilemmas of disclosing parental HIV status and testing children for HIV in Uganda. Health Policy Plan 2008, 23(1):36-42.

33. Mkwanazi NB, Rochat TJ, Imrie J, Bland RM: Disclosure of maternal HIV-status to children: considerations for research and practice in sub-Saharan Africa. Future Virology 2012, 7(12):1159-82.

34. Bor J, Bärnighausen T, Newell C, Tanser F, Newell M-L: Social exposure to an antiretroviral treatment programme in rural KwaZulu-Natal Exposition sociale à un programme de traitement antirétroviral dans les régions rurales du KwaZulu-Natal. Trop Med Int Health 2011, 16(8):988-994.

35. Rotheram-Borus M, Swendeman D, Lee S-J, Li L, Amani B, Nartey M: Interventions for families affected by HIV. Translational Behavioral Medicine 2011, 1(2):313-326

36. Cluver L: Children of the AIDS pandemic. Nature 2011, 474(7349):27-29

37. Cluver L, Orkin M, Boyes ME, Gardner F, Nikelo J: AIDS-orphanhood and caregiver HIV/AIDS sickness status: effects on psychological symptoms in South African youth. J Pediatr Psychol 2012, 37(8):857-867.

38. Bhana A: Middle Childhood and Pre-adolescance. In Promoting Mental Health in Scare-Resource Contexts. Edited by Peterson I, Bhana A, Flisher A, Swartz L, Richter L. Cape Town, South Africa: HSRC Press; 2010:124-142.

39. Zaidi J, Grapsa E, Tanser F, Newell M-L, Bärnighausen T: HIV prevalence trends after scale-up of antiretroviral treatment: a population-based study in a poor rural community in KwaZulu-Natal. Washington DC, USA: XIX International AIDS Conference; 2012

40. Tanser F, Barnighausen T, Grapsa E, Newell M: Effect of ART coverage on rate of new HIV infections in a hyper-endemic, rural population: South Africa. In 19th Conference on Retroviruses and Opportunistic Infections CROI 5-8 Mar 2012 2012. Seattle Washington, USA: Washington State Convention Center; 2012.

41. Bärnighausen $T$, Tanser $F$, Newell M-L: Lack of a decline in HIV incidence in a rural community with high HIV prevalence in South Africa, 20032007. AIDS Res Hum Retroviruses 2009, 25(4):405-409.

42. Hill C, Hosegood V, Newell M-L: Children's care and living arrangements in a high HIV prevalence area in rural South Africa. Vulnerable Children and Youth Studies 2008, 3(1):65-77.

43. Nyirenda M, McGrath N, Newell M-L: Gender differentials in the impact of parental death: adolescent's sexual behaviour and risk of HIV infection in rural South Africa. Vulnerable Children and Youth Studies 2010, 5(3):284-296.

44. Craig P, Dieppe P, Macintyre S, Michie S, Nazareth I, Petticrew M: Developing and evaluating complex interventions: the new Medical Research Council guidance. BMJ 2008, 337(sep29_1):a1655-a1655.

45. World Health Organization. Guideline on HIV disclosure counselling for children up to 12 years of age. Geneva, WHO. 2011

46. Derlega VJ, Winstead BA, Greene K, Serovich J, Elwood WN: Reasons for HIV disclosure/nondisclosure in close relationships: testing a model of HIVdisclosure decision making. J Soc Clin Psychol 2004, 23(6):747-767.

47. Hosegood V, Preston-Whyte E, Busza J, Moitse S, Timaeus IM: Revealing the full extent of households' experiences of HIV and AIDS in rural South Africa. Social Science \&amp; Medicine 2007, 65(6):1249-1259.

48. Desmond C: Consequences of HIV for children: avoidable or inevitable? AIDS Care 2009, 21(sup1):98-104

49. Hosegood V, Madhavan S: Data availability on men's involvement in families in sub-Saharan Africa to inform family-centred programmes for children affected by HIV and AIDS. J Int AIDS SOC 2010, 13(Suppl 2):S5

50. Richter L: An introduction to family-centred services for children affected by HIV and AIDS. J Int AIDS Soc 2010, 13:1-6.

51. Richter LM, Sherr L, Adato M, Belsey M, Chandan U, Desmond C, Drimie S, Haour-Knipe M, Hosegood V, Kimou J: Strengthening families to support children affected by HIV and AIDS. AIDS Care 2009, 21(S1):3-12.

52. Institute of Medicine. Health and Behavior: The Interplay of Biological Behavioral, and Societal Influences: The National Academies Press; 2001. Downloaded from http://www.nap.edu/catalog.php?record_id=9838\#orgs.

53. Qiao S, Li X, Stanton B: Theoretical models of parental HIV disclosure: a critical review. AIDS Care 2012, 6:6.

54. Letteney S, LaPorte HH: Deconstructing stigma: perceptions of HIVseropositive mothers and their disclosure to children. Soc Work Health Care 2004, 38(3):105-123. 
55. Kennedy D, Cowgill B, Bogart L, Corona R, Ryan G, Murphy D, Nguyen T, Schuster M: Parents' disclosure of their HIV infection to their children in the context of the family. AIDS Behav 2010, 14(5):1095-1105.

56. Letteney S: Disrupted caregiving and maternal HIV disease: a proposed model for evaluating HIV-affected children's psychosocial adjustment. Soc Work Health Care 2010, 49(8):753-763.

57. King E, De Silva M, Stein A, Patel V: Interventions for improving the psychosocial well-being of children affected by HIV and AIDS. Cochrane Database Syst Rev 2009, 2.

58. Pequegnat W, Bell CC, Allison S: The Role of Families Among Orphans and Vulnerable Children in Confronting HIV/AIDS in Sub-Saharan Africa. In Family and HIV/AIDS. Edited by Pequegnat W, Bell CC. New York: Springer; 2012:173-194.

59. Kruse GR, Chapula BT, Ikeda S, Nkhoma M, Quiterio N, Pankratz D, Mataka K, Chi BH, Bond V, Reid SE: Burnout and use of HIV services among health care workers in Lusaka District, Zambia: a cross-sectional study. Human Resources for Health 2009, 7(1):55.

60. Uebel KE, Nash J, Avalos A: Caring for the caregivers: models of HIV/AIDS care and treatment provision for health care workers in Southern Africa. J Infect Dis 2007, 196(Supplement 3):500-504.

61. Petersen I, Lund C, Bhana A, Flisher AJ: A task shifting approach to primary mental health care for adults in South Africa: human resource requirements and costs for rural settings. Health Policy Plan 2012, 27(1):42-51.

62. McPake B, Mensah K: Task shifting in health care in resource-poor countries. Lancet 2008, 372(9642):870-871.

63. Lesch A, Swartz L, Kagee A, Moodley K, Kafaar Z, Myer L, Cotton M: Paediatric HIV/AIDS disclosure: towards a developmental and processoriented approach. AIDS Care 2007, 19(6):811-816.

64. Christ GH, Christ AE: Current approaches to helping children cope with a parent's terminal illness. CA: A Cancer Journal for Clinicians 2006, 56(4):197-212.

65. Geballe SD: Guardianship as a therapeutic option. Child Adolesc Psychiatr Clin N Am 2000, 9(2):407-424

66. Sieh DS, Meijer AM, Oort FJ, Visser-Meily JM, Van der Leij DA: Problem behavior in children of chronically ill parents: a meta-analysis. Clin Child Fam Psychol Rev 2010, 13(4):384-397.

67. Bland R, Coovadia H, Coutsoudis A, Rollins N, Newell M: Cohort profile: mamanengane or the Africa centre vertical transmission study. Int J Epidemiol 2010, 39(2):351-360.

68. Murphy DA, Marelich WD, Armistead L, Herbeck DM, Payne DL: Anxiety/ stress among mothers living with HIV: effects on parenting skills and child outcomes. AIDS Care 2010, 22(12):1449-1458.

69. Callaghan M, Ford N, Schneider $\mathrm{H}$ : A systematic review of task shifting for HIV treatment and care in Africa. Human Resources for Health 2010; 8:8.

70. Hoffmann C, Mills L, Gallant J: Future of HIV/AIDS Care in Low- and Middle- Income Countries. In: Celentano D, Beyrer C, editors. Public Health Aspects of HIV/AIDS in Low and Middle Income Countries: Springer New York; 2009. p. 41-69.

71. Selke HM, Kimaiyo S, Sidle JE, Vedanthan R, Tierney WM, Shen C, Denski CD, Katschke AR, Wools-Kaloustian K: Task-shifting of antiretroviral delivery from health care workers to persons living with HIV/AIDS: clinical outcomes of a community-based program in Kenya. J Acquir Immune Defic Syndr 2010, 55(4):483-490.

72. Rahman A, Malik A, Sikander S, Roberts C, Creed F: Cognitive behaviour therapy-based intervention by community health workers for mothers with depression and their infants in rural Pakistan: a cluster-randomised controlled trial. Lancet 2008, 372(9642):902-909.

73. Patel V, Weiss HA, Chowdhary N, Naik S, Pednekar S, Chatterjee S, De Silva MJ, Bhat B, Araya R, King M, et al: Effectiveness of an intervention led by lay health counsellors for depressive and anxiety disorders in primary care in Goa, India (MANAS): a cluster randomised controlled trial. Lancet 2010, 376(9758):2086-2095.

74. Bachelor A: Comparison and relationship to outcome of diverse dimensions of the helping alliance as seen by client and therapist. Psychotherapy: Theory, Research, Practice, Training 1991, 28(4):534-549.
75. Lambert MJ: Psychotherapy outcome research: Implications for integrative and eclectical therapists. In Handbook of psychotherapy integration. Edited by Goldfried JCNMR. New York, NY, US: Basic Books; 1992:94-129.

76. Rubin A: Practice effectiveness: more grounds for optimism. Soc Work 1985, 30(6):469-476.

doi:10.1186/1471-2458-13-147

Cite this article as: Rochat et al:: Maternal HIV disclosure to HIVuninfected children in rural South Africa: a pilot study of a family-based intervention. BMC Public Health 2013 13:147.

\section{Submit your next manuscript to BioMed Central and take full advantage of:}

- Convenient online submission

- Thorough peer review

- No space constraints or color figure charges

- Immediate publication on acceptance

- Inclusion in PubMed, CAS, Scopus and Google Scholar

- Research which is freely available for redistribution

Submit your manuscript at www.biomedcentral.com/submit
C) BioMed Central 